\title{
Nitrogen enrichment lowers Betula pendula green and yellow leaf stoichiometry irrespective of effects of elevated carbon dioxide
}

\author{
A. J. Esmeijer-Liu • R. Aerts • W. M. Kürschner • \\ R. Bobbink • A. F. Lotter • J. T. A. Verhoeven
}

Received: 3 April 2008 / Accepted: 15 September 2008 / Published online: 9 October 2008

(C) The Author(s) 2008. This article is published with open access at Springerlink.com

\begin{abstract}
Elevated carbon dioxide $\left(\mathrm{CO}_{2}\right)$ and increased nitrogen $(\mathrm{N})$ availability generally increase deciduous tree biomass and alter green and yellow leaf stoichiometry. This paper investigates whether this also applies to Betula pendula (Birch). The effects of elevated atmospheric $\mathrm{CO}_{2}(600 \mathrm{ppmv})$ and increased $\mathrm{N}$ availability $\left(50\right.$ and $100 \mathrm{~kg} \mathrm{~N}^{-1}$ year $^{-1}$ ) of differential inorganic nitrogen type (ammonium, nitrate and ammonium nitrate) on net primary production (NPP) and green/yellow leaf C:N of Betula pendula saplings were studied for 3 years. The combination of both factors raised NPP, but elevated $\mathrm{CO}_{2}$ alone did not. In green leaves, increased $\mathrm{N}$ availability raised $\mathrm{N}$ concentrations, outweighing
\end{abstract}

Editorial Responsibility: Per Ambus.

A. J. Esmeijer-Liu $(\triangle) \cdot$ R. Bobbink $\cdot$ J. T. A. Verhoeven Institute of Environmental Biology, Landscape Ecology, Utrecht University,

NL-3508 TB Utrecht, The Netherlands

e-mail: A.J.Liu@uu.nl

R. Aerts

Institute of Ecological Sciences,

Department of Systems Ecology,

VU University Amsterdam,

NL-1081 HV Amsterdam, The Netherlands

W. M. Kürschner • A. F. Lotter

Institute of Environmental Biology, Palaeoecology,

Laboratory of Palaeobotany and Palynology,

Utrecht University,

NL-3584 CD Utrecht, The Netherlands decreases caused by elevated $\mathrm{CO}_{2}$. After senescence, increased $\mathrm{N}$ concentrations were found at $100 \mathrm{~kg} \mathrm{~N}$ $\mathrm{ha}^{-1}$ year $^{-1}$, also leading to a lower $\mathrm{C}: \mathrm{N}$ ratio. Although a lower $\mathrm{C}: \mathrm{N}$ ratio may increase the decomposition rate during early decomposition, it may have the opposite effect during later decomposition stages. This, in combination with increased biomass production and possibly lower soil $\mathrm{pH}$ values, might increase soil $\mathrm{C}$ storage. However, due to the complexity of soil $\mathrm{C}$ formation and related processes this remains unsure.

Keywords Elevated $\mathrm{CO}_{2} \cdot$ Nitrogen enrichment . $\mathrm{N}$ concentration $\cdot \mathrm{C}: \mathrm{N} \cdot$ Resorption $\cdot$ Betula pendula

\section{Introduction}

Since the Industrial Revolution, the concentration of atmospheric carbon dioxide $\left(\mathrm{CO}_{2}\right)$ has increased exponentially from approximately $285 \mathrm{ppmv}$ in 1850 to 369 ppmv in 2000 (Friedli et al. 1986; Keeling and Whorf 2005), and for 2100 values between 400 and 1000 ppmv are predicted (Enting et al. 1994; IPCC 2001). Nitrogen oxide $\left(\mathrm{NO}_{x}\right)$ and ammonia $\left(\mathrm{NH}_{y}\right)$ emissions have also increased since the second half of the nineteenth century and have led to an increase in wet deposition of nitrate $\left(\mathrm{NO}_{3}{ }^{-}\right)$and ammonium $\left(\mathrm{NH}_{4}{ }^{+}\right)$, dry deposition of gaseous nitric acid, ammonia and $\mathrm{NO}_{x}$, and particulate $\mathrm{NO}_{3}{ }^{-}$(Pitcairn et al. 1995; Freyer et al. 1996; Asman et al. 1998; Erisman et al. 1998b; Holland et al. 1999; Lawrence et al. 
2000; Fowler et al. 2004). Despite emission reduction in some parts of Western Europe since the 1990s, nitrogen $(\mathrm{N})$ emission levels are still expected to rise in other parts of the world (Dentener et al. 2006).

The general effects of elevated $\mathrm{CO}_{2}$ on $\mathrm{C}_{3}$ plants include increased photosynthesis, water use efficiency, net primary production (NPP), and decreased $\mathrm{N}$ concentration (or an increased C:N ratio; Pettersson and McDonald 1992; Ceulemans and Mousseau 1994; Mcguire et al. 1995; Penuelas and Estiarte 1997; Poorter et al. 1997; Curtis and Wang 1998; Gifford et al. 2000; DeLucia and Thomas 2000; Norby et al. 2001; Finzi et al. 2002; Coley et al. 2002). Because N availability limits plant growth in many terrestrial ecosystems, an increase in $\mathrm{N}$ availability generally has a positive effect on plant growth and/or biomass, total plant $\mathrm{N}$, area-based plant $\mathrm{N}$ concentration, and specific leaf area (Bobbink et al. 1998; Bauer et al. 2001; Lipson and Nasholm 2001; Pal et al. 2005; van den Berg et al. 2005b; Reich et al. 2006).

While the single factor effects of elevated $\mathrm{CO}_{2}$ and $\mathrm{N}$ availability on the physiology of plants are well understood, the effects of combined increases of both resources have not been investigated as thoroughly. Several studies have been undertaken on agricultural crops (Nakamura et al. 1999; Li et al. 2004; Pal et al. 2005 a.o.) or grassland plants and shrubs (van der Heijden et al. 2000; Heijmans et al. 2001; Reich et al. 2006). Less studies have focused on deciduous trees as either seedlings or adults and only a few include birch species (Mcguire et al. 1995; Lippert et al. 1996; Curtis and Wang 1998). In general, both elevated $\mathrm{CO}_{2}$ and increased $\mathrm{N}$ availability were generally found to increase biomass.

Apart from the physiological effects, elevated $\mathrm{CO}_{2}$ and increased $\mathrm{N}$ availability may also influence deciduous leaf and litter stoichiometry. The effects of elevated $\mathrm{CO}_{2}$ and increased $\mathrm{N}$ availability on tree litter quality can be opposite and are therefore not yet fully understood. While yellow leaf $\mathrm{C}: \mathrm{N}$ may be unaffected or positively affected by elevated $\mathrm{CO}_{2}$, it may be unaffected to negatively affected in response to increased $\mathrm{N}$ availability (Cotrufo et al. 1995; Hirschel et al. 1997; Scherzer et al. 1998; Norby et al. 1999; Gifford et al. 2000; Norby et al. 2001). Some studies on deciduous tree species have investigated both factors in combination, but most often the emphasis was solely on primary production and yellow leaf $\mathrm{C}: \mathrm{N}$ values have not been reported
(Pettersson et al. 1993; Mcguire et al. 1995; Bauer et al. 2001).

Although higher $\mathrm{N}$ availability generally stimulates plant growth and biomass, there may be differences in plant responses depending on the chemical composition of the $\mathrm{N}$ source. Generally, plants from circumneutral, alkaline, and aerobic soils prefer $\mathrm{NO}_{3}{ }^{-}$as their $\mathrm{N}$ source, while those from acid and anaerobic soils often prefer $\mathrm{NH}_{4}{ }^{+}$(Gigon and Rorison 1972; de Graaf et al. 1998; van den Berg et al. 2005a). Other authors indicate that plant species of acidic soils where $\mathrm{NH}_{4}^{+}$is usually the predominant form of inorganic N (Troelstra et al. 1990) may be less negatively affected by increased $\mathrm{NH}_{4}{ }^{+}$concentrations, but that they do not perform better on either $\mathrm{NH}_{4}{ }^{+}$or $\mathrm{NO}_{3}{ }^{-}$as their sole $\mathrm{N}$ source (Gigon and Rorison 1972; Falkengren-Grerup 1995). This is probably caused by differential effects of both $\mathrm{N}$ species on plant functioning, e.g., through soil $\mathrm{pH}$ or microbial competition and preference (Kaye and Hart 1997; Britto and Kronzucker 2002; Paulissen et al. 2004; van den Berg et al. 2005a; Guo et al. 2007). However, studies on the effects of $\mathrm{N}$ enrichment on deciduous trees generally have applied $\mathrm{N}$ as $\mathrm{NH}_{4} \mathrm{NO}_{3}$, combining both $\mathrm{NH}_{4}{ }^{+}$and $\mathrm{NO}_{3}{ }^{-}$(Bauer et al. 2001). Only very few studies have made a distinction between $\mathrm{NH}_{4}-\mathrm{N}$ and $\mathrm{NO}_{3}-\mathrm{N}$ (Crabtree and Bazzaz 1993; Templer and Dawson 2004) and therefore information on the possible differential effects of $\mathrm{NH}_{4}{ }^{+}$and $\mathrm{NO}_{3}{ }^{-}$ addition on deciduous tree species is very limited.

Both the increase in biomass and changes in green and yellow leaf stoichiometry or $\mathrm{N}$ concentration may influence the decomposition process and, finally, soil $\mathrm{C}$ storage. Early studies indicate that a higher $\mathrm{N}$ concentration in litter would increase the decomposition rate in general (Swift et al. 1979). However, later studies indicate that decomposition is divided into two stages and that macronutrients, such as N, only influence decomposition during the early stage which may last for a few months (Berg 2000). In the late stage, as the concentration of recalcitrant lignin fractions increases, decomposition rates are increasingly suppressed. Here, Berg (2000) found a clearly significant and negative relationship between the initial $\mathrm{N}$ concentration of the litter and decomposition. This author indicates that this is probably due to the repressed formation of lingo-lytic enzymes in whiterot fungi by low-molecular $\mathrm{N}$ compounds and/or the formation of recalcitrant complexes by the reaction of 
ammonia or amino acids with lignin degradation products. In the late stage of decomposition leading towards the formation of soil organic matter, the inhibition of the decomposition rate by increased litter $\mathrm{N}$ concentrations may be so strong that decomposition reaches a limit value at which total mass losses virtually stop and contribute to soil C storage (Berg and Meentemeyer 2002).

Reviewing the effects of elevated $\mathrm{CO}_{2}$ and increased $\mathrm{N}$ availability in general is difficult enough across species, but upgrading results towards forest or ecosystem level is even more problematic. At first, most experiments were short-term, and were performed on a small scale with (young) seedlings. Norby et al. (1999) found that most of the results of these experiments are qualitatively correct compared to results of experiments over several growing seasons under field conditions. Furthermore, Körner et al. (2005) indicate that large, mature forest trees respond physiologically to elevated atmospheric $\mathrm{CO}_{2}$ in a manner similar to the younger trees used in most studies. Many deciduous Northern-Hemisphere forests include or are even dominated by birch species. Because of the relatively small number of studies on this species, the validation of general effects of elevated $\mathrm{CO}_{2}$ and $\mathrm{N}$ availability combined on plant production, leaf physiology and $\mathrm{N}$ source performance is very limited, if not absent. The very few studies on Birch specifically may possibly restrain conclusions on the $\mathrm{C}$ and $\mathrm{N}$ cycles in these systems. Therefore, the present study has focused on birch, Betula pendula specifically.

This study addresses the following main research questions. (a) What is the combined effect of increased $\mathrm{CO}_{2}$ and $\mathrm{N}$ enrichment on NPP and yellow leaf stoichiometry of $B$. pendula; and (b) is the response of $B$. pendula to increased $\mathrm{N}$ dependent on the proportion of inorganic $\mathrm{N}$ species? The following hypotheses have been formulated:

1. Both elevated $\mathrm{CO}_{2}$ and increased $\mathrm{N}$ availability will lead to a higher NPP. Combined, they will lead to an even higher NPP.

2. Yellow leaves grown at elevated $\mathrm{CO}_{2}$ will have a higher $\mathrm{C}: \mathrm{N}$ ratio than those grown at ambient $\mathrm{CO}_{2}$. $\mathrm{N}$ enrichment will lead to a lower yellow leaf $\mathrm{C}: \mathrm{N}$ ratio. Combined, the $\mathrm{C}: \mathrm{N}$ ratio will be lowered compared to a control situation due to the stronger effect of $\mathrm{N}$ enrichment.
3. Because $B$. pendula is a species that characteristically grows on acid and medium-nutritious soils, it will produce more biomass when given $\mathrm{NH}_{4}{ }^{+}$ instead of $\mathrm{NO}_{3}{ }^{-}$.

To test these hypotheses, a greenhouse experiment was performed with $B$. pendula saplings for a period of 3 years in ambient and elevated $\mathrm{CO}_{2}$, and with three different $\mathrm{N}$ treatments: $\mathrm{NH}_{4}{ }^{+}, \mathrm{NO}_{3}{ }^{-}$, and $\mathrm{NH}_{4} \mathrm{NO}_{3}$.

\section{Materials and methods}

\section{Experimental conditions}

The study was carried out from 2003 to 2005 in the greenhouse complex of the "VU University Amsterdam". Two separate chambers, one with ambient $\mathrm{CO}_{2}$ $( \pm 380$ ppmv $)$ and one with elevated $\mathrm{CO}_{2}( \pm 600$ ppmv), were both connected to a temperature regulation system. Night and day temperatures were $10^{\circ} \mathrm{C} /$ $15^{\circ} \mathrm{C}$ in winter and $15^{\circ} \mathrm{C} / 20^{\circ} \mathrm{C}$ during summer, respectively. The temperature was gradually raised in spring or lowered in fall. The $\mathrm{CO}_{2}$ was regulated year-round during daylight hours. The $B$. pendula saplings, half-siblings, were 2 years old at the start of the experiment. All individuals had one main stem without significant side branches and were between 50 and $80 \mathrm{~cm}$ long. They were planted in containers of $26 \mathrm{~cm}$ diameter and $22.5 \mathrm{~cm}$ height in April 2003. A double layer of root-cloth prevented roots from growing out of the drainage holes. They were planted in poor heath soil that originated from the province of Drenthe, the Netherlands. The soil $\mathrm{pH}$ was 4.5-5.0.

The full factorial setup of the experiment included two levels of $\mathrm{CO}_{2}$ (ambient and $600 \mathrm{ppmv}$ ), three different forms of $\mathrm{N}$ additions $\left(\mathrm{NH}_{4}{ }^{+}, \mathrm{NO}_{3}{ }^{-}\right.$, $\left.\mathrm{NH}_{4} \mathrm{NO}_{3}\right)$ and three different levels $\left(0 \mathrm{~kg} \mathrm{~N}^{-1}\right.$ year $^{-1}, 50 \mathrm{~kg} \mathrm{~N} \mathrm{ha}^{-1}$ year $^{-1}$, and $100 \mathrm{~kg} \mathrm{~N} \mathrm{ha}^{-1}$ year $^{-1}$ ). Eight replicates (saplings in pots) were used per treatment. The $0 \mathrm{~kg} \mathrm{~N}^{-1}$ year $^{-1}$ treatments were used as a common control for the three different forms of $\mathrm{N}$ additions, resulting in a total of 112 trees. The three levels of $\mathrm{N}$ represent environments with very low $\mathrm{N}$ deposition (0) close to background levels, medium to high deposition (50), and very high deposition (100). These levels are based on presentday and historical deposition levels in the Nether- 
lands. The $\mathrm{N}$ level of $100 \mathrm{~kg} \mathrm{ha}^{-1}$ year $^{-1}$ is quite high, but has occurred in specific areas in the Netherlands during the 1980s and is not uncommon in agriculture. The 0,50 and $100 \mathrm{~kg} \mathrm{~N}^{-1}$ year $^{-1}$ treatments will be referred to as control, $50-\mathrm{N}$, and $100-\mathrm{N}$, respectively. The $\mathrm{N}$ addition was applied in nine monthly portions each year, beginning just before the leaf buds opened (25th April 2003, 17th February 2004, and 18th February 2005). A $100-\mathrm{ml}$ dilution of $1 / 10$ Hoagland's nutrient solution without N (Hewitt and Smith 1975) was used as a base nutrient solution to which the experimental $\mathrm{N}$ was added in the form of $\mathrm{NH}_{4} \mathrm{Cl}, \mathrm{NaNO}_{3}$, and $\mathrm{NH}_{4} \mathrm{NO}_{3}$. Subsequently, the plants were watered to field capacity with demineralised water and this was repeated in weeks without treatment. The position of the saplings in the greenhouse was changed every 2 weeks in 2003 and 2004, and every month in 2005 according to a randomization scheme. Pest control was performed both manually (once in 2003) and by spraying with Duoflor (once in 2003 and 2004).

\section{Measurements}

As this was a long-term experiment, any destructive growth or biomass measurements other than leaf sampling and length and stem thickness measurements were not performed during the first 2 years. In the last experimental year (2005) several plant parameters were determined. As a measure of biomass, the total dry weight of only the woody parts of the saplings (root and stem) was measured by harvesting. We assume that the responses of the total dry weight of woody parts to the treatments are representative for the responses of other biomass parameters (such as leaf biomass and total plant biomass, which were not measured). To determine the $\mathrm{C}$ and $\mathrm{N}$ concentration of green (sampled in June) and yellow leaves (sampled at various times during the end of the growing season), three air-dried leaves of each tree were randomly selected. The leaves were ground to a homogeneous powder with an Eppendorf grinder (Retsch MM301) using $2 \mathrm{ml}$ Eppendorf containers and $5 \mathrm{~mm}$ diameter glass balls. Prior to analysis, the samples were dried at $70^{\circ} \mathrm{C}$ for 24 hours. Approximately $3 \mathrm{mg}$ of the sample was weighed into tin foil containers $(2 \times 5 \mathrm{~mm})$ and analysed for $\mathrm{C}$ and $\mathrm{N}$ concentration using a $\mathrm{CHN}$ elemental analyzer (Interscience CE instruments, EA 11110 CHNS-O).
Senescence, the process that influences the yellow leaf stoichiometry is best understood by taking into account both nitrogen resorption efficiency (NRE) and resorption proficiency. Therefore, yellow leaf $\mathrm{N}$ concentration is depicted as $\mathrm{N}$ proficiency according to (Killingbeck 1996) and the mean NRE was calculated using the mean green and yellow leaf $\mathrm{N}$ concentration. According to Killingbeck (1996) N concentrations lower than $0.7 \%$ are indicative for complete resorption, between $0.7 \%$ and $1.0 \%$ indicate intermediate resorption, and $>1.0 \%$ stand for incomplete resorption.

\section{Statistical analysis}

All results are or have been randomly cut down to an equal sample size which was $n=7$ for average combined total weight of root and stem, $n=5$ for average $\mathrm{C}: \mathrm{N}$ of green leaves, and $n=4$ for average $\mathrm{C}$ : $\mathrm{N}$ of yellow leaves. The overall influence of $\mathrm{CO}_{2}, \mathrm{~N}$ type, and $\mathrm{N}$ level on all parameters was tested using analysis of variance (three-way ANOVA). In these analyses the $\mathrm{N}$ types were considered "unique". In case of interaction in the overall analyses, the data was split for $\mathrm{N}$ type and/or $\mathrm{N}$ level. To specifically test for differences between $\mathrm{NH}_{4}$ and $\mathrm{NO}_{3}$ treatments, separate variance analyses were performed on the data of these two treatments. The results of the statistical analyses are shown in Tables 1 and 2. Parameters were tested for normality and homogeneity of error variances. Deviations were, however, ignored because the data followed a symmetrical distribution and group sizes within the analysis were identical. Under these circumstances ANOVA is known to be robust against these violations. Differences were accepted as significant at $p<0.05$. All analyses have been performed using SPSS 11.5 for Windows.

\section{Results}

In the overall analysis, averaging all factors, elevated $\mathrm{CO}_{2}$ increased the total dry weight of $B$. pendula saplings by $11 \%(p<0.05 ;$ Table 1$)$. Increased $\mathrm{N}$ additions also resulted in a higher dry weight $(p<$ 0.01 ). Relative to the control, the $50-\mathrm{N}$ and $100-\mathrm{N}$ addition treatments increased the total dry weight by 122 and $147 \%$, respectively. The type of $\mathrm{N}$ addition did not affect the dry weight. When tested for $\mathrm{N}$ levels 
Table 1 Average values for total dry weight, green leaf $\mathrm{N}$ and yellow leaf $\mathrm{C}: \mathrm{N}$ ratio and overall analysis

\begin{tabular}{|c|c|c|c|}
\hline & $\mathrm{CO}_{2}$ & N-level & N-type \\
\hline & $380 / 600$ ppmv & $0 / 50 / 100 \mathrm{~kg} \mathrm{~N} \mathrm{ha}^{-1}$ year $^{-1}$ & Control $/ \mathrm{NH}_{4}{ }^{+} / \mathrm{NO}_{3}{ }^{-} / \mathrm{NH}_{4} \mathrm{NO}_{3}$ \\
\hline Total dry weight (g) & $102 / 113^{*}$ & $50 / 111 / 123^{* *}$ & $50 / 120 / 113 / 119$ \\
\hline Green leaf $N\left(\mathrm{mg} \mathrm{g}^{-1} \mathrm{~d} w \mathrm{t}\right)$ & $23.7 / 18.6 * * *$ & $14.1 / 18.1 / 26.6^{* * *}$ & $14.1 / 21.3 / 23.4 / 22.4$ \\
\hline Yellow leaf $\mathrm{C}: \mathrm{N}$ ratio & $69.4 / 79.1$ & $91.5 / 85.6 / 57.0 * * *$ & $91.5 / 67.3 / 73.3 / 73.4$ \\
\hline
\end{tabular}

Average values for $B$. pendula total dry weight, green leaf $\mathrm{N}$ and yellow leaf $\mathrm{C}: \mathrm{N}$ ratio and overall statistical analysis ${ }^{*} p<0.05 ; * * p<0.01 ; * * * p<0.001$

separately (Table 2), it appeared that elevated $\mathrm{CO}_{2}$ increased the total dry weight in the $50-\mathrm{N}$ treatment, but not in the control-N or $100-\mathrm{N}$ treatment. Also, in the 50-N treatment, there was a differential effect of the N-types on the total dry weight (trend towards increased total dry weight when $\mathrm{NH}_{4}^{+}$was given), which was absent at the 100-N level.

Elevated $\mathrm{CO}_{2}$ resulted in an average overall reduction in green leaf $\mathrm{N}$ concentration of $21 \%$ compared to ambient $\mathrm{CO}_{2}(p<0.001$; Fig. 1, Table 1). N additions increased the green leaf $\mathrm{N}$ concentration $(p$ $<0.001$ ), i.e., by $29 \%$ and $90 \%$ in the $50-\mathrm{N}$ and $100-\mathrm{N}$ treatments compared to the control, respectively. The split for $\mathrm{N}$ level (Table 2) showed that elevated $\mathrm{CO}_{2}$ decreased the green leaf $\mathrm{N}$ concentration in the $50-\mathrm{N}$ and $100-\mathrm{N}$ treatment, but not in the control-N treatment. The overall analysis of the yellow leaf $\mathrm{C}$ : $\mathrm{N}$ ratio showed that $\mathrm{N}$ enrichment had a reducing effect $(p<0.001$; Fig. 2, Table 1$)$. There was no difference between the control-N and 50-N levels, but the $100-\mathrm{N}$ level was $38 \%$ lower than the control-N level and $33 \%$ lower than the $50-\mathrm{N}$ level. The resorption proficiency is complete for both control treatments according to the levels given in Killingbeck (1996; Table 3). At the ambient $\mathrm{CO}_{2}$ level, all $50-\mathrm{N}$ treatments showed higher NRE values than the control, resulting in complete resorption proficiency. The ambient $100-\mathrm{N}$ treatments however showed varying NRE values (higher, similar and lower than the control NRE) and all resulted in incomplete resorption proficiencies, shown by higher than normal $\mathrm{N}$ concentrations.

At elevated $\mathrm{CO}_{2}$ two out of tree $50-\mathrm{N}$ treatments had an NRE that was higher than the control NRE and all had complete resorption proficiencies. The NRE of two out of three elevated $\mathrm{CO}_{2} 100-\mathrm{N}$ treatments were even higher than the control-N and 50-N levels, but in the end all had only intermediate or incomplete resorption proficiencies. There was no overall $\mathrm{CO}_{2}$ effect.

The separate analysis with the data of the $\mathrm{NH}_{4}^{+}$and $\mathrm{NO}_{3}{ }^{-}$treatments showed that there was no difference in the effects of these two types on total weight or yellow leaf $\mathrm{C}: \mathrm{N}$ ratio (data not shown). The effects on green leaf $\mathrm{N}$ concentration showed interaction with both $\mathrm{CO}_{2}$ and $\mathrm{N}$ level. At ambient $\mathrm{CO}_{2}$ the $\mathrm{NO}_{3}{ }^{-}$treatments yielded a higher green leaf $\mathrm{N}$ concentration at both $\mathrm{N}$

Table 2 Average values for total dry weight, green leaf $\mathrm{N}$ and yellow leaf C:N ratio and detailed analyses

\begin{tabular}{|c|c|c|c|}
\hline & & $\mathrm{CO}_{2}$ & N-type \\
\hline & & $380 / 600 \mathrm{ppmv}$ & $\mathrm{NH}_{4}^{+} / \mathrm{NO}_{3}{ }^{-} / \mathrm{NH}_{4} \mathrm{NO}_{3}$ \\
\hline \multirow[t]{3}{*}{ Total dry weight (g) } & Control & $51.8 / 48.3$ & - \\
\hline & $50 \mathrm{~kg} \mathrm{~N} \mathrm{ha}^{-1}$ year $^{-1}$ & $101 / 121^{* * *}$ & $119 / 107 / 107^{\wedge}$ \\
\hline & $100 \mathrm{~kg} \mathrm{~N}^{-1}$ year $^{-1}$ & $119 / 128$ & $121 / 119 / 131$ \\
\hline \multirow[t]{2}{*}{ Green leaf $\mathrm{N}\left(\mathrm{mg} \mathrm{g}^{-1} \mathrm{~d} w \mathrm{t}\right)$} & Control & $14.9 / 13.2$ & - \\
\hline & $50 \mathrm{~kg} \mathrm{~N} \mathrm{ha}{ }^{-1}$ year $^{-1}$ & $20.6 / 15.6^{* *}$ & $16.7 / 18.9 / 18.7$ \\
\hline \multirow[t]{4}{*}{ Yellow leaf C:N ratio } & $100 \mathrm{~kg} \mathrm{~N} \mathrm{ha}^{-1}$ year $^{-1}$ & $29.7 / 23.5^{* *}$ & $25.9 / 27.8 / 26.1$ \\
\hline & Control & $89.6 / 93.5$ & - \\
\hline & $50 \mathrm{~kg} \mathrm{~N} \mathrm{ha}{ }^{-1}$ year $^{-1}$ & $83.2 / 88.1$ & $89.8 / 83.3 / 83.8$ \\
\hline & $100 \mathrm{~kg} \mathrm{~N} \mathrm{ha}^{-1}$ year $^{-1}$ & $48.8 / 65.2$ & $44.8 / 63.3 / 63.0$ \\
\hline
\end{tabular}

Average values for $B$. pendula total dry weight, green leaf $\mathrm{N}$ and yellow leaf $\mathrm{C}: \mathrm{N}$ ratio and detailed statistical analyses $\wedge p<0.10 ; * p<0.05 ; * * p<0.01 ; * * * p<0.001$ 
Fig. 1 Average N concentration of green leaves. Average $\mathrm{N}$ concentration of green leaves ( $\mathrm{mg} \mathrm{g}^{-1} \pm$ s.e.) of $B$. pendula saplings $(n=5)$ in response to different $\mathrm{N}$ and $\mathrm{CO}_{2}$ treatments. White bars represent ambient $\mathrm{CO}_{2}(380$ ppmv), black bars represent elevated $\mathrm{CO}_{2}$ (600 ppmv). $\mathrm{N}$ doses (in $\mathrm{kg} \mathrm{N}^{-1} \mathrm{year}^{-1}$ ) are indicated by 50 or 100 , control stands for 0

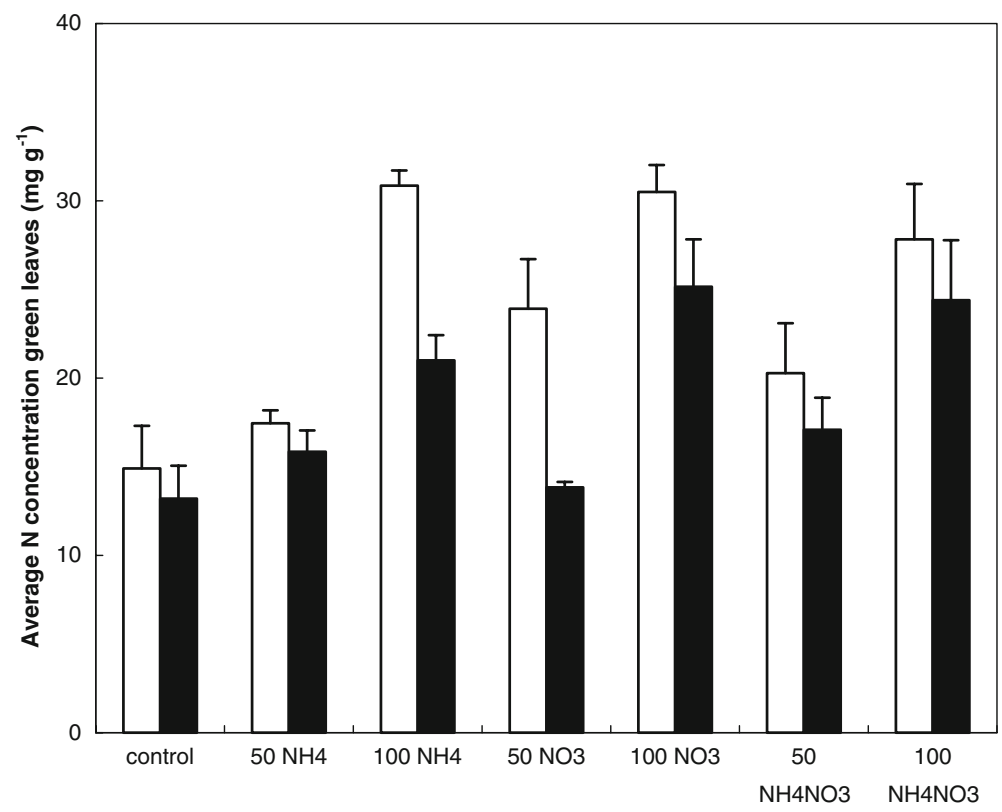

levels. However, at elevated $\mathrm{CO}_{2}$ the $\mathrm{NO}_{3}{ }^{-}$treatments yielded a higher green leaf $\mathrm{N}$ concentration only at the 100-N level. At the 50-N level, $\mathrm{NH}_{4}{ }^{+}$resulted in a higher green leaf $\mathrm{N}$ concentration.

\section{Discussion}

The main questions raised in this study focused on the effects of elevated $\mathrm{CO}_{2}$ and enhanced $\mathrm{N}$ availability on $B$. pendula NPP and leaf stoichiometry, and on the differential effects of inorganic nitrogen species on $B$. pendula functioning.

\section{Effects on NPP}

The first hypothesis, which stated that both elevated $\mathrm{CO}_{2}$ and increased $\mathrm{N}$ availability separately would lead to a higher NPP and that the combination of both would lead to an even higher NPP, is only partly
Fig. 2 Average C:N ratio of yellow leaves. Average C:N ratio of yellow leaves $( \pm$ s.e. $)$ of $B$. pendula saplings ( $n=$ 4) in response to different $\mathrm{N}$ and $\mathrm{CO}_{2}$ treatments. White bars represent ambient $\mathrm{CO}_{2}$ (380 ppmv), black bars represent elevated $\mathrm{CO}_{2}(600$ ppmv). $\mathrm{N}$ doses (in $\mathrm{kg} \mathrm{N}$ ha $^{-1}$ year $^{-1}$ ) are indicated by 50 or 100 , control stands for 0

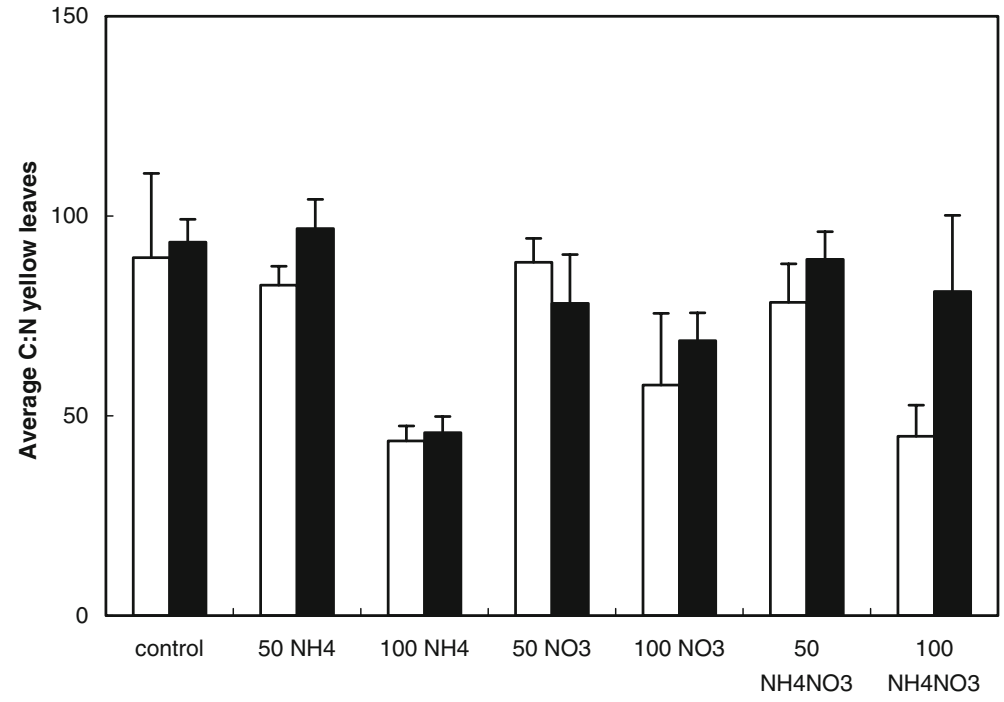


Table 3 Average nitrogen resorption efficiency and resorption proficiency of yellow leaves

\begin{tabular}{|c|c|c|c|c|c|c|c|c|}
\hline & \multicolumn{4}{|c|}{380 ppmv $\mathrm{CO}_{2}$} & \multicolumn{4}{|c|}{600 ppmv $\mathrm{CO}_{2}$} \\
\hline & NRE $(\%)$ & NRE relative to control & $\% \mathrm{~N}$ & Proficiency & NRE (\%) & NRE relative to control & $\% \mathrm{~N}$ & Proficiency \\
\hline Control & 12.1 & & 0.67 & Complete & 15.2 & & 0.52 & Complete \\
\hline $50 \mathrm{NH}_{4}$ & 21.0 & + & 0.62 & Complete & 20.1 & + & 0.53 & Complete \\
\hline $100 \mathrm{NH}_{4}$ & 15.9 & + & 1.19 & Incomplete & 5.5 & - & 1.13 & Incomplete \\
\hline $50 \mathrm{NO}_{3}$ & 31.5 & + & 0.59 & Complete & 10.2 & - & 0.69 & Complete \\
\hline $100 \mathrm{NO}_{3}$ & 12.7 & 0 & 1.30 & Incomplete & 23.5 & + & 0.78 & Intermediate \\
\hline $50 \mathrm{NH}_{4} \mathrm{NO}_{3}$ & 19.6 & + & 0.69 & Complete & 19.4 & + & 0.58 & Complete \\
\hline $100 \mathrm{NH}_{4} \mathrm{NO}_{3}$ & 7.3 & - & 1.28 & Incomplete & 23.5 & + & 0.77 & Intermediate \\
\hline
\end{tabular}

supported by our data. The NPP is only raised by $\mathrm{CO}_{2}$ when additional $\mathrm{N}$ is available. This result is not in agreement with two meta-studies where NPP (or growth/biomass) was increased by $\mathrm{CO}_{2}$ irrespective of $\mathrm{N}$ level (Mcguire et al. 1995; Curtis and Wang 1998). However, in both these studies it was found that low nitrogen availability constrains the response of growth to elevated $\mathrm{CO}_{2}$, which is corroborated by a study of Finzi et al. (2002). Here, in this experiment, the control treatment did not receive any $\mathrm{N}$ during the whole experiment apart from the initial soil $\mathrm{N}$ and some (indoor) background deposition. This $\mathrm{N}$ limitation probably prevented any biomass increase due to elevated $\mathrm{CO}_{2}$. The absence of a $\mathrm{CO}_{2}$ effect at the 100$\mathrm{N}$ level is probably due to a limitation by one or more other elements, such as phosphorus or potassium. The increase in NPP by N addition in the N-amended treatments was, however, at least tenfold higher than the effect of elevated $\mathrm{CO}_{2}$. A similar difference in effect size was also found by Lippert et al. (1996). When these results are interpreted in the context of the functioning of birch-dominated ecosystems, the effects of elevated $\mathrm{CO}_{2}$ and increased $\mathrm{N}$ deposition on $\mathrm{C}$ and $\mathrm{N}$ cycling are highly dependent on the intensity of both the $\mathrm{C}$ and the $\mathrm{N}$ enrichment. Our results indicate that in ecosystems with very low atmospheric $\mathrm{N}$ deposition (such as the northernmost parts of Europe, North America and Asia) it is not very likely that elevated $\mathrm{CO}_{2}$ alone will cause an increase in the biomass production. However, deposition is already increasing in these low-deposition areas. Ecosystems that already are subject to increased $\mathrm{N}$ deposition, have higher biomass production than before the onset of $\mathrm{N}$ enrichment. Elevated $\mathrm{CO}_{2}$ will add to that increase. Elevated $\mathrm{CO}_{2}$ (up to a certain level) leads to more biomass production, which implies that more $\mathrm{C}$ is fixed. Whether or not the additionally fixed $\mathrm{C}$ is retained within the ecosystem is dependent on the balance between biomass production and decomposition. The effects of elevated $\mathrm{CO}_{2}$ on decomposition are related to the $\mathrm{N}$ richness of the system. $\mathrm{C}$ and $\mathrm{N}$ concentrations in green and yellow leaves can shed more light on this topic.

\section{Effects on green leaf $\mathrm{C}: \mathrm{N}$}

Increased $\mathrm{N}$ availability significantly increased the $\mathrm{N}$ concentration in the green leaves, as was also observed in several other studies (Ruohomaki et al. 1996; Tomassen et al. 2003). At the 50-N level this increase is accompanied by an increase in biomass while at the $100-\mathrm{N}$ level only the green leaf $\mathrm{N}$ concentration increases. The increased $\mathrm{N}$ concentration is (partly for the $50-\mathrm{N}$ treatment) the effect of luxury consumption of $\mathrm{N}$, where $\mathrm{N}$ is stored as $\mathrm{N}$-rich amino acids (Tomassen et al. 2003). Elevated $\mathrm{CO}_{2}$ has, on the other hand, an opposite effect on $\mathrm{N}$ concentration in leaves, in some treatments even to the point where $\mathrm{N}$-amended trees showed no difference compared with the control treatment (Fig. 1). Mcguire et al. (1995), as well as Poorter et al. (1997) reviewed the effects of elevated $\mathrm{CO}_{2}$ and also found an overall decrease in green leaf $\mathrm{N}$. This is most likely the result of $\mathrm{N}$ dilution by an increase in nonstructural (Poorter et al. 1997) and structural carbohydrates at elevated $\mathrm{CO}_{2}$. Green leaf $\mathrm{N}$ concentration 
influences photosynthesis and palatability, but it does not influence the decomposition system directly (although $\mathrm{N}$ leaching from green leaves to the decomposition system will be positively related to $\mathrm{N}$ concentration). Leaves of deciduous trees withdraw nutrients from their leaves during senescence and the outcome of that process, the stoichiometry of yellow leaves, directly influences the decomposition process.

\section{Effects on yellow leaf C:N}

The hypothesis that yellow leaves grown at elevated $\mathrm{CO}_{2}$ have a higher $\mathrm{C}: \mathrm{N}$ ratio than those grown at ambient $\mathrm{CO}_{2}$ is rejected. Though not significant, $\mathrm{C}: \mathrm{N}$ was higher in almost all treatments, up to nearly $50 \%$ in the $100-\mathrm{NH}_{4} \mathrm{NO}_{3}$ treatment. The absence of a significant $\mathrm{CO}_{2}$ effect on yellow leaf $\mathrm{C}: \mathrm{N}$, while it was present in the green leaf $\mathrm{C}: \mathrm{N}$ ratio, may indicate that the effect was indeed absent. However, because Coley et al. (2002) found an increase in yellow leaf $\mathrm{C}: \mathrm{N}$, and a meta-analysis by Norby et al. (2001) showed a decrease in yellow leaf $\mathrm{N}$ which is assumed to work through an increase in $\mathrm{C}: \mathrm{N}$, it could also be that the effect was there but that we have not been able to detect it. Firstly, because the yellow leaf C concentration was also reduced slightly (not shown), which may have (partly) leveled out the change in $\mathrm{N}$ concentration. Secondly, because the small number of replicates and relatively large variance combined resulted in relatively low statistical power in our analysis. Apart from this lack in $\mathrm{CO}_{2}$ effect on yellow leaf $\mathrm{C}: \mathrm{N}$, there was also no difference in the onset and duration of senescence between the two $\mathrm{CO}_{2}$ treatments.

The hypothesis that $\mathrm{N}$ enrichment would to lead to a lower yellow leaf $\mathrm{C}: \mathrm{N}$ ratio, can be accepted. At the $100-\mathrm{N}$ level either the withdrawal efficiency of $\mathrm{N}$ during leaf abscission was reduced, or the initial $\mathrm{N}$ concentration was so high that withdrawal was not sufficient to reach a minimum $\mathrm{N}$ concentration in the leaf. Therefore, we focus on the resorption proficiency and efficiency. Compared to other studies, see Aerts (1996) for a review, the NRE values found in this study are relatively low. This may be caused by our method; the autumn night temperatures in the greenhouse remained higher than outdoors and this may have influenced the NRE. However, although our values may need to be examined with care when compared to other studies, the relative differences between the treatments in our study remain valid. According to the resorption proficiency levels from Killingbeck (1996) resorption is complete for both control treatments. $\mathrm{N}$ is translocated to roots and stems at the end of the season to support growth in the next year, leaving only a minimum in the leaf. At the $50-\mathrm{N}$ level, the NRE is higher than the relative control treatment in five out of six treatments. This higher $\mathrm{NRE}$ is, apparently, sufficient to reach $\mathrm{N}$ concentrations that are indicative for complete resorption. In four out of six $100-\mathrm{N}$ treatments, $\mathrm{N}$ is translocated more efficiently or similarly to the control treatments, but this is not enough to reach complete proficiency as all $100-\mathrm{N}$ treatments show intermediate to incomplete resorption proficiency. However, it seems that there may be a different response between ambient and elevated $\mathrm{CO}_{2}$ conditions, with the latter yielding more intermediate $\mathrm{N}$ percentages.

Other authors have already indicated that nutrient translocation may proceed more efficiently under eutrophic conditions than under mesotrophic conditions(Chapin and Kedrowski 1983; Aerts 1990), probably due to the more mobile state of additionally formed N-rich amino-acids (Tomassen et al. 2003). This is (partly) corroborated by our data. The results seem to indicate that at ambient $\mathrm{CO}_{2}$ very high $\mathrm{N}$ availability will cause a higher $\mathrm{N}$ concentration in yellow leaves. Elevated $\mathrm{CO}_{2}$ combined with very high $\mathrm{N}$ availability will also cause a higher $\mathrm{N}$ concentration in yellow leaves, but to a lesser degree than at the ambient level. At the ecosystem level this indicates that at present-day $\mathrm{CO}_{2}$, a moderately increased $\mathrm{N}$ deposition will not cause a decrease in the $\mathrm{C}: \mathrm{N}$ ratio of the litter. However, at high $\mathrm{N}$ deposition levels, higher $\mathrm{N}$ concentrations are left in the leaf after senescence. These high $\mathrm{N}$ deposition levels were reached during the 1980s in the Netherlands, but may also occur in systems with dry deposition and a large aerodynamic roughness length such as forests and heaths (Erisman et al. 1998a). This can lead to a distinctly lower C:N ratio of litter that enters the decomposition system. Elevated $\mathrm{CO}_{2}$ will not reverse this effect but may diminish it slightly.

Although decomposition is influenced by both biotic and abiotic factors such as $\mathrm{pH}$, temperature, moisture and the presence of a microbial community, here we focus on the effects of litter quality characterized by the $\mathrm{C}: \mathrm{N}$ ratio. While litter with a lower initial $\mathrm{C}: \mathrm{N}$ ratio (or higher $\mathrm{N}$ concentration) 
may or may not lead to a higher initial decomposition rate (Aerts and de Caluwe 1997; de Angelis et al. 2000; Norby et al. 2001; Limpens and Berendse 2003; Soudzilovskaia et al. 2007), Berg (2000) and Berg and Meentemeyer (2002) found that during the late stage of decomposition higher $\mathrm{N}$ concentrations retard the decomposition rate and that other elements such as calcium or manganese may influence the decomposition rate of foliar litter in later stages as well (Berg et al. 2007). Our study indicates that litter quality, measured as yellow leaf $\mathrm{C}: \mathrm{N}$, is enhanced at very high $\mathrm{N}$ availability irrespective of the effects of elevated $\mathrm{CO}_{2}$. The values found, from above 90 for the control treatments to 57 for the $100-\mathrm{N}$ treatments are expected to greatly increase the initial "digestibility" of the material for the decomposer community (Swift et al. 1979; Melillo et al. 1982), resulting in higher decomposition rates. However, in the long term, the initially higher $\mathrm{N}$ concentration may lead to a lower late stage decomposition rate (Berg 2000). This relation may possibly lead to, or add up to an increase in soil $\mathrm{C}$ storage in deciduous forest stands with very high $\mathrm{N}$ deposition (Berg and Meentemeyer 2002; Berg et al. 2007).

\section{Effects of inorganic $\mathrm{N}$ species on biomass}

The third hypothesis, that $B$. pendula will perform better when given $\mathrm{NH}_{4}{ }^{+}$instead of $\mathrm{NO}_{3}{ }^{-}$has to be rejected. In the overall analysis, no parameter showed differential effects for the $\mathrm{N}$ types. This was confirmed by analysis of the data of solely the $\mathrm{NH}_{4}{ }^{+}$and $\mathrm{NO}_{3}{ }^{-}$treatments. Apparently, B. pendula, which naturally grows on more or less acid and anaerobic soils does not prefer nor is more adapted to $\mathrm{NH}_{4}-\mathrm{N}$. Experiments on this subject show conflicting results. Generally, plants from circum-neutral, alkaline, and aerobic soils prefer $\mathrm{NO}_{3}{ }^{-}$as their $\mathrm{N}$ source, while those from acid and anaerobic soils often prefer $\mathrm{NH}_{4}{ }^{+}$ (Gigon and Rorison 1972; de Graaf et al. 1998; van den Berg et al. 2005a), although this is not always found (Crabtree and Bazzaz 1993). Other authors indicate that plant species of acidic soils where $\mathrm{NH}_{4}{ }^{+}$ is usually the predominant form of inorganic $\mathrm{N}$ (Troelstra et al. 1990) may be less affected by increased $\mathrm{NH}_{4}{ }^{+}$concentrations, but that they do not perform better on either $\mathrm{NH}_{4}{ }^{+}$or $\mathrm{NO}_{3}{ }^{-}$as their sole $\mathrm{N}$ source (Gigon and Rorison 1972; Falkengren-Grerup 1995). Our results indicate that elevated $\mathrm{NH}_{4}$ deposition does not cause a larger NPP or biomass production for $B$. pendula than a similarly elevated $\mathrm{NO}_{3}{ }^{-}$deposition. At the ecosystem level this means that although wet and dry $\mathrm{N}$ deposition may show spatial variation in the composition in the dominant $\mathrm{N}$ type $\left(\mathrm{NH}_{4}{ }^{+}\right.$or $\left.\mathrm{NO}_{3}{ }^{-}\right)$, this will probably not cause differential effects on birch-dominated systems. Only in some specific cases, where birch species with a narrow $\mathrm{pH}$ range in the neutral to alkaline values occur (such as B. alleghaniensis with a $\mathrm{pH}$ range between 7 and 8), $\mathrm{N}$ deposition in the form of $\mathrm{NH}_{4}{ }^{+}$ may cause a species shift towards more acidic tolerant birch species.

\section{Effects on the soil C storage}

Soil C storage is the positive result of organic matter input and organic matter decomposition, and is influenced by multiple factors such as NPP, litter production and chemistry, mineralization, immobilisation, temperature, $\mathrm{pH}$, moisture, nutrients and soilorganisms. Although the single-factor responses for most of these are known, they can be misleading when extrapolating to the real system because of in vitro- effects, short-term effects and (unknown) interactions and/or feedbacks (Hyvonen et al. 2007).

Although our results show that the combination of elevated $\mathrm{CO}_{2}$ and increased $\mathrm{N}$ availability raised plant NPP and that the $\mathrm{C}: \mathrm{N}$ ratio of leaf litter after senescence remained lower at high-N addition levels, we can only speculate on the effects on the soil C storage. Most straightforward, if nothing else changes, then increased litter production by the combination of elevated $\mathrm{CO}_{2}$ and increased $\mathrm{N}$ could possibly result in an increased soil $\mathrm{C}$ storage (Schlesinger and Lichter 2001; Jastrow et al. 2005). The same is true if solely the effect of the lower C:N ratio on the decomposition rate is considered, because in that phase the formation of soil organic matter is negatively influenced by higher $\mathrm{N}$ concentrations (Berg 2000; Berg and Meentemeyer 2002). Also, if the higher availability of $\mathrm{N}$ (through higher $\mathrm{N}$ deposition) is followed by a decrease in soil $\mathrm{pH}$, this may also decrease the decomposition rate or mass loss (Swift et al. 1979; Neuvonen and Suomela 1990) and increase soil $\mathrm{C}$ storage. In this chain of processes a higher atmospheric $\mathrm{CO}_{2}$ concentration and elevated $\mathrm{N}$ deposition could therefore lead to an increase in the soil C storage. 
However, this study only encompasses effects on Birch leaf litter, which makes up only a fraction of the total soil $\mathrm{C}$ input because soil organic matter input consists also from leachate, pollen, flowers, seeds, branches, stems and roots from several tree and other plant species. Also, less direct effects may lessen or reverse increased soil $\mathrm{C}$ storage such as the effect of a lower $\mathrm{pH}$ on the presence of decomposing fungi, bacteria or soil macro-organisms (Swift et al. 1979) or the effect of a higher atmospheric $\mathrm{CO}_{2}$ concentration on temperature and therefore on the actual evapotranspiration (Aerts 1997) or (short or long-term) soil respiration (Melillo et al. 2002) for example. The final result on soil $\mathrm{C}$ storage is therefore unknown.

Acknowledgements This experiment was performed in the greenhouse complex of the Vrije Universiteit Amsterdam. We would like to thank Prof. Dr. R. Aerts for making this possible. Also we would like to thank all supporting staff, colleagues and students for their valuable support during field and laboratory work, and Dr. E. Dorland for his constructive comments on earlier versions of this paper.

Open Access This article is distributed under the terms of the Creative Commons Attribution Noncommercial License which permits any noncommercial use, distribution, and reproduction in any medium, provided the original author(s) and source are credited.

\section{References}

Aerts R (1990) Nutrient use efficiency in evergreen and deciduous species from heathlands. Oecologia 84:391-397

Aerts R (1996) Nutrient resorption from senescing leaves of perennials: are there general patterns? J Ecol 84:597-608 doi: $10.2307 / 2261481$

Aerts R (1997) Climate, leaf litter chemistry and leaf litter decomposition in terrestrial ecosystems: a triangular relationship. Oikos 79:439-449 doi:10.2307/3546886

Aerts R, de Caluwe H (1997) Initial litter respiration as indicator for long-term leaf litter decomposition of Carex species. Oikos 80:353-361 doi:10.2307/3546603

Asman WAH, Sutton MA, Schjorring JK (1998) Ammonia: emission, atmospheric transport and deposition. New Phytol 139:27-48 doi:10.1046/j.1469-8137.1998.00180.x

Bauer GA, Berntson GM, Bazzaz FA (2001) Regenerating temperate forests under elevated $\mathrm{CO}_{2}$ and nitrogen deposition: comparing biochemical and stomatal limitation of photosynthesis. New Phytol 152:249-266 doi:10.1046/ j.0028-646X.2001.00255.x

Berg B (2000) Litter decomposition and organic matter turnover in northern forest soils. For Ecol Manag 133:13-22

Berg B, Meentemeyer V (2002) Litter quality in a north European transect versus carbon storage potential. Plant Soil 242:83-92 doi:10.1023/A:1019637807021
Berg B, Steffen KT, McClaugherty C (2007) Litter decomposition rate is dependent on litter $\mathrm{Mn}$ concentrations. Biogeochem 82:29-39 doi:10.1007/s10533-006-9050-6

Bobbink R, Hornung M, Roelofs JGM (1998) The effects of air-borne nitrogen pollutants on species diversity in natural and semi-natural European vegetation. J Ecol 86:717-738 doi:10.1046/j.1365-2745.1998.8650717.x

Britto DT, Kronzucker HJ (2002) $\mathrm{NH}_{4}^{+}$toxicity in higher plants: a critical review. J Plant Physiol 159:567-584 doi:10.1078/0176-1617-0774

Ceulemans R, Mousseau M (1994) Tansley Review No. 71: effects of elevated atmospheric $\mathrm{CO}_{2}$ on woody plants. New Phytol 127:425-446 doi:10.1111/j.1469-8137.1994. tb03961.x

Chapin FS, Kedrowski RA (1983) Seasonal changes in nitrogen and phosphorus fractions and autumn retranslocation in evergreen and deciduous taiga trees. Ecol 64:376-391 doi: $10.2307 / 1937083$

Coley PD, Massa M, Lovelock CE, Winter K (2002) Effects of elevated $\mathrm{CO}_{2}$ on foliar chemistry of saplings of nine species of tropical tree. Oecologia 133:62-69 doi:10.1007/ s00442-002-1005-6

Cotrufo MF, Ineson P, Roberts JD (1995) Decomposition of birch leaf litters with varying $\mathrm{C}$ to $\mathrm{N}$ ratios. Soil Biol Biochem 27:1219-1221 doi:10.1016/0038-0717(95) 00043-E

Crabtree RC, Bazzaz FA (1993) Seedling response of 4 birch species to simulated nitrogen deposition-ammonium vs nitrate. Ecol Appl 3:315-321 doi:10.2307/1941834

Curtis PS, Wang XZ (1998) A meta-analysis of elevated $\mathrm{CO}_{2}$ effects on woody plant mass, form, and physiology. Oecologia 113:299-313 doi:10.1007/s004420050381

de Angelis P, Chigwerewe KS, Mugnozza GES (2000) Litter quality and decomposition in a $\mathrm{CO}_{2}$-enriched Mediterranean forest ecosystem. Plant Soil 224:31-41 doi:10.1023/ A: 1004790328560

de Graaf MCC, Bobbink R, Roelofs JGM, Verbeek PJM (1998) Differential effects of ammonium and nitrate on three heathland species. Plant Ecol 135:185-196 doi:10.1023/ A: 1009717613380

DeLucia EH, Thomas RB (2000) Photosynthetic responses to $\mathrm{CO}_{2}$ enrichment of four hardwood species in a forest understory. Oecologia 122:11-19 doi:10.1007/PL00008827

Dentener F, Stevenson D, Ellingsen K, Van Noije T, Schultz M, Amann $M$ et al (2006) The global atmospheric environment for the next generation. Environ Sci Technol 40:3586-3594 doi:10.1021/es0523845

Enting IG, Wigley TML, Heimann M (1994) Future emissions and concentrations of carbon dioxide: key ocean/atmosphere/land analyses. pp. 1-130.

Erisman JW, Bleeker A, Van Jaarsveld H (1998a) Atmospheric deposition of ammonia to semi-natural vegetation in the Netherlands - methods for mapping and evaluation. Atmos Environ 32:481-489 doi:10.1016/S1352-2310(97)00276-8

Erisman JW, Mennen MG, Fowler D, Flechard CR, Spindler G, Gruner A et al (1998b) Deposition monitoring in Europe. Environ Monit Assess 53:279-295 doi:10.1023/ A:1005818820053

Falkengren-Grerup U (1995) Interspecies differences in the preference of ammonium and nitrate in vascular plants. Oecologia 102:305-311 doi:10.1007/BF00329797 
Finzi AC, DeLucia EH, Hamilton JG, Richter DD, Schlesinger WH (2002) The nitrogen budget of a pine forest under free air $\mathrm{CO}_{2}$ enrichment. Oecologia 132:567-578 doi:10.1007/ s00442-002-0996-3

Fowler D, Muller JBA, Sheppard LJ (2004) The GaNE programme in a global perspective. Water Air Soil Pollut Focus 4:3-8 doi:10.1007/s11267-004-3008-2

Freyer HD, Kobel K, Delmas RJ, Kley D, Legrand MR (1996) First results of N-15/N-14 ratios in nitrate from alpine and polar ice cores. Tellus Ser B-Chem Phys Meteorol 48:93-105 doi:10.1034/j.1600-0889.1996.00009.x

Friedli H, Lotscher H, Oeschger H, Siegenthaler U, Stauffer B (1986) Ice core record of the ${ }^{13} \mathrm{C} /{ }^{12} \mathrm{C}$ ratio of atmospheric $\mathrm{CO}_{2}$ in the past two centuries. Nature 324:237-238 doi: $10.1038 / 324237 \mathrm{a} 0$

Gifford RM, Barrett DJ, Lutze JL (2000) The effects of elevated $\left[\mathrm{CO}_{2}\right]$ on the $\mathrm{C}: \mathrm{N}$ and $\mathrm{C}: \mathrm{P}$ mass ratios of plant tissues. Plant Soil 224:1-14 doi:10.1023/A:1004790612630

Gigon A, Rorison IH (1972) The response of some ecologically distinct plant species to nitrate- and to ammoniumnitrogen. J Ecol 60:93-102 doi:10.2307/2258043

Guo S, Zhou Y, Shen Q, Zhang F (2007) Effect of ammonium and nitrate nutrition on some physiological processes in higher plants - growth, photosynthesis, photorespiration, and water relations. Plant Biol 9:21-29 doi:10.1055/s2006-924541

Heijmans MMPD, Berendse F, Arp WJ, Masselink AK, Klees $\mathrm{H}$, de Visser W et al (2001) Effects of elevated carbon dioxide and increased nitrogen deposition on bog vegetation in the Netherlands. J Ecol 89:268-279 doi:10.1046/ j.1365-2745.2001.00547.x

Hewitt EJ, Smith TA (1975) Plant mineral nutrition. English University Press, London

Hirschel G, Korner C, Arnone JA (1997) Will rising atmospheric $\mathrm{CO}_{2}$ affect leaf litter quality and in situ decomposition rates in native plant communities? Oecologia 110: 387-392

Holland EA, Dentener FJ, Braswell BH, Sulzman JM (1999) Contemporary and pre-industrial global reactive nitrogen budgets. Biogeochem 46:7-43

Hyvonen R, Agren GI, Linder S, Persson T, Cotrufo MF, Ekblad A, Freeman M, Grelle A, Janssens IA, Jarvis PG, kellomaki S, Lindroth A, Loustau D, Lundmark T, Norby RJ, Oren R, Pilegaard K, Ryan MG, Sigurdsson BD, Stromgren M, van Oijen M, Wallin G (2007) The likely impact of elevated [CO2], nitrogen deposition, increased temperature and management on carbon sequestration in temperate and boreal forest ecosystems: a literature review. New Phytol 173:463-480 doi:10.1111/j.1469-8137.2007.01967.x

IPCC (2001) Climate Change 2001: Synthesis Report. A Contribution of Working Groups I, II and III to the Third Assessment Report of the Intergovernmental Panel on Climate Change. Ed. R T a t C W T e Watson. Cambridge University Press, Cambridge, UK, pp. 1-398

Jastrow JD, Miller RM, Matamala R, Norby RJ, Boutton TW, Rice CW et al (2005) Elevated atmospheric carbon dioxide increases soil carbon. Glob Chang Biol 11:2057-2064 doi:10.1111/j.1365-2486.2005.01077.x

Kaye JP, Hart SC (1997) Competition for nitrogen between plants and soil microorganisms. Trends Ecol Evol 12:139143 doi:10.1016/S0169-5347(97)01001-X
Keeling CD, Whorf TP (2005) Atmospheric $\mathrm{CO}_{2}$ records from sites in the SIO sampling network.

Killingbeck KT (1996) Nutrients in senesced leaves: keys to the search for potential resorption and resorption proficiency. Ecol 77:1716-1727 doi:10.2307/2265777

Körner C, Asshoff R, Bignucolo O, Hättenschwiler S, Keel SG, Peláez-Riedl S et al (2005) Exposing a mature Swiss forest to elevated $\mathrm{CO}_{2}$ increased the flux of carbon through the trees and soils but did not increase net forest growth or carbon storage. Science 309:1360-1362 doi:10.1126/ science. 1113977

Lawrence GB, Goolsby DA, Battaglin WA, Stensland GJ (2000) Atmospheric nitrogen in the Mississippi River Basin-emissions, deposition and transport. Sci Total Environ 248:87-99 doi:10.1016/S0048-9697(99)00533-1

Li Z, Yagi K, Sakai H, Kobayashi K (2004) Influence of elevated $\mathrm{CO}_{2}$ and nitrogen nutrition on rice plant growth, soil microbial biomass, dissolved organic carbon and dissolved $\mathrm{CH}_{4}$. Plant Soil 258:81-90 doi:10.1023/B: PLSO.0000016538.28110.d8

Limpens J, Berendse F (2003) How litter quality affects mass loss and $\mathrm{N}$ loss from decomposing Sphagnum. Oikos 103:537-547 doi:10.1034/j.1600-0706.2003.12707.x

Lippert M, Haberle KH, Steiner K, Payer HD, Rehfuess KE (1996) Interactive effects of elevated $\mathrm{CO}_{2}$ and O-3 on photosynthesis and biomass production of clonal 5-yearold Norway spruce [Picea abies (L) Karst] under different nitrogen nutrition and irrigation treatments. Trees-Struct Funct 10:382-392

Lipson D, Nasholm T (2001) The unexpected versatility of plants: organic nitrogen use and availability in terrestrial ecosystems. Oecologia 128:305-316 doi:10.1007/s004420100693

Mcguire AD, Melillo JM, Joyce LA (1995) The role of nitrogen in the response of forest net primary production to elevated atmospheric carbon-dioxide. Annu Rev Ecol Syst 26:473-503 doi:10.1146/annurev.es.26.110195.002353

Melillo JM, Aber JD, Muratore JF (1982) Nitrogen and lignin control of hardwood leaf litter decomposition dynamics. Ecol 63:621-626 doi:10.2307/1936780

Melillo JM, Steudler PA, Aber JD, Newkirk K, Lux H, Bowles FP et al (2002) Soil warming and carbon-cycle feedbacks to the climate system. Science 298:2173-2176 doi:10.1126/ science. 1074153

Nakamura T, Koike T, Lei T, Ohashi K, Shinano T, Tadano T (1999) The effect of $\mathrm{CO}_{2}$ enrichment on the growth of nodulated and non-nodulated isogenic types of soybean raised under two nitrogen concentrations. Pholosynth 37:61-70. doi:10.1023/A:1007018929795

Neuvonen S, Suomela J (1990) The effect of simulated acid rain on pine needle and birch leaf litter decomposition. J Appl Ecol 27:857-872 doi:10.2307/2404382

Norby RJ, Wullschleger SD, Gunderson CA, Johnson DW, Ceulemans R (1999) Tree responses to rising $\mathrm{CO}_{2}$ in field experiments: implications for the future forest. Plant Cell Environ 22:683-714 doi:10.1046/j.1365-3040.1999. 00391.x

Norby RJ, Cotrufo MF, Ineson P, O’Neill EG, Canadell JG (2001) Elevated $\mathrm{CO}_{2}$, litter chemistry, and decomposition: a synthesis. Oecologia 127:153-165 doi:10.1007/s004420000615

Pal M, Rao LS, Jain V, Srivastava AC, Pandey R, Raj A et al (2005) Effects of elevated $\mathrm{CO}_{2}$ nitrogen on wheat growth 
and photosynthesis. Biol Plant 49:467-470 doi:10.1007/ s10535-005-0031-8

Paulissen MPCP, van der Ven PJM, Dees AJ, Bobbink R (2004) Differential effects of nitrate and ammonium on three fen bryophyte species in relation to pollutant nitrogen input. New Phytol 164:451-458 doi:10.1111/ j.1469-8137.2004.01196.x

Penuelas J, Estiarte M (1997) Trends in plant carbon concentration and plant demand for $\mathrm{N}$ throughout this century. Oecologia 109:69-73 doi:10.1007/s004420050059

Pettersson R, McDonald AJS (1992) Effects of elevated carbon-dioxide concentration on photosynthesis and growth of small birch plants (Betula pendula Roth.) at optimal nutrition. Plant Cell Environ 15:911-919 doi:10.1111/j.1365-3040.1992.tb01023.x

Pettersson R, McDonald AJS, Stadenberg I (1993) Response of small birch plants (Betula pendula Roth) to elevated $\mathrm{CO}_{2}$ and nitrogen supply. Plant Cell Environ 16:1115-1121 doi:10.1111/j.1365-3040.1996.tb02069.x

Pitcairn CER, Fowler D, Grace J (1995) Deposition of fixed atmospheric nitrogen and foliar nitrogen-content of bryophytes and Calluna vulgaris (L) hull. Environ Pollut 88:193-205 doi:10.1016/0269-7491(95)91444-P

Poorter H, van Berkel Y, Baxter R, den Hertog J, Dijkstra P, Gifford RM et al (1997) The effect of elevated $\mathrm{CO}_{2}$ on the chemical composition and construction costs of leaves of $27 \mathrm{C}_{3}$ species. Plant Cell Environ 20:472-482 doi:10.1046/ j.1365-3040.1997.d01-84.x

Reich PB, Hobbie SE, Lee T, Ellsworth DS, West JB, Tilman D et al (2006) Nitrogen limitation constrains sustainability of ecosystem response to $\mathrm{CO}_{2}$. Nature 440:922-925 doi:10.1038/nature04486

Ruohomaki K, Chapin FS, Haukioja E, Neuvonen S, Suomela J (1996) Delayed inducible resistance in mountain birch in response to fertilization and shade. Ecol 77:2302-2311 doi: $10.2307 / 2265732$

Scherzer AJ, Rebbeck J, Boerner REJ (1998) Foliar nitrogen dynamics and decomposition of yellow-poplar and eastern white pine during four seasons of exposure to elevated ozone and carbon dioxide. For Ecol Manag 109:355-366

Schlesinger WH, Lichter J (2001) Limited carbon storage in soil and litter of experimental forest plots under increased atmospheric CO2. Nature 411:466-469 doi:10.1038/35078060

Soudzilovskaia NA, Onipchenko VG, Cornelissen JHC, Aerts R (2007) Effects of fertilisation and irrigation on 'foliar afterlife' in alpine tundra. J Veg Sci 18:755-766 doi:10.1658/ 1100-9233(2007)18[755:EOFAIO]2.0.CO;2

Swift MJ, Heal OW, Anderson JM (1979) Decomposition in terrestrial ecosystems. Blackwell, UK

Templer PH, Dawson TE (2004) Nitrogen uptake by four tree species of the Catskill Mountains, New York: implications for forest N dynamics. Plant Soil 262:251-261

Tomassen HBM, Smolders AJP, Lamers LPM, Roelofs JGM (2003) Stimulated growth of Betula pubescens and Molinia caerulea on ombrotrophic bogs: role of high levels of atmospheric nitrogen deposition. J Ecol 91:357370 doi:10.1046/j.1365-2745.2003.00771.x

Troelstra SR, Wagenaar R, De Boer W (1990) Nitrification in Dutch heathland soils. 1. General soil characteristics and nitrification in undisturbed soil cores. Plant Soil 127:179192 doi:10.1007/BF00014424

van den Berg LJL, Dorland E, Vergeer P, Hart MAC, Bobbink R, Roelofs JGM (2005a) Decline of acid-sensitive plant species in heathland can be attributed to ammonium toxicity in combination with low $\mathrm{pH}$. New Phytol 166:551-564 doi:10.1111/j.1469-8137.2005.01338.x

van den Berg LJL, Tomassen HBM, Roelofs JGM, Bobbink R (2005b) Effects of nitrogen enrichment on coastal dune grassland: a mesocosm study. Environ Pollut 138:77-85 doi:10.1016/j.envpol.2005.02.024

van der Heijden E, Verbeek SK, Kuiper PJC (2000) Elevated atmospheric $\mathrm{CO}_{2}$ and increased nitrogen deposition: effects on $\mathrm{C}$ and $\mathrm{N}$ metabolism and growth of the peat moss Sphagnum recurvum P. Beauv. var. mucronatum (Russ.) Warnst. Glob Chang Biol 6:201-212 doi:10.1046/ j.1365-2486.2000.00303.x 